\title{
GEOGRAPHICAL DISTRIBUTION OF THE GENUS MYRMOTERAS,
} INCLUDING THE DESCRIPTION OF A NEW SPECIES (HYMENOPTERA : FORMICIDAE)

\author{
By ROBERT E. GREGG \\ Department of Biology, University of Colorado
}

In 1925, Carlo Emery summarized the accumulated knowledge concerning the ant genus Myrmoteras in the Genera Insectorum, Fasc. 183, p. 36, and listed four species with their general distribution in portions of Malay and the East Indies. The following brief anatomical diagnosis of the genus is adapted from Emery, and gives the important distinguishing characteristics.

Worker: monomorphic.

Head relatively large and angular; eyes enormous, very convex, covering one-half to three-quarters of the sides of the head; ocelli present; a deep, transverse groove behind the ocelli separates a prominent occipital bulge from the vertex; the bulge shows a marked median depression. Clypeus produced and with a sinuate anterior border continuing into rather sharp clypeal teeth laterally. Frontal area and epistomal suture distinct. Mandibles slightly longer than the head, approximated at their bases, narrow and almost straight, armed with long teeth evenly spaced along the medial border; the mandibular apex with two quite long, sharp teeth, the terminal one representing the recurved tip of the mandible; between these two teeth two small denticles may be present. Maxillary palps 6-segmented; labial palps 4-segmented. Frontal carinae obsolete. Antennal fossae remote from the epistomal suture; antennae filiform and composed of 12 segments.

Thorax resembles that of Oecophylla; pronotum and epinotum prominent and convex, mesonotum depressed and 


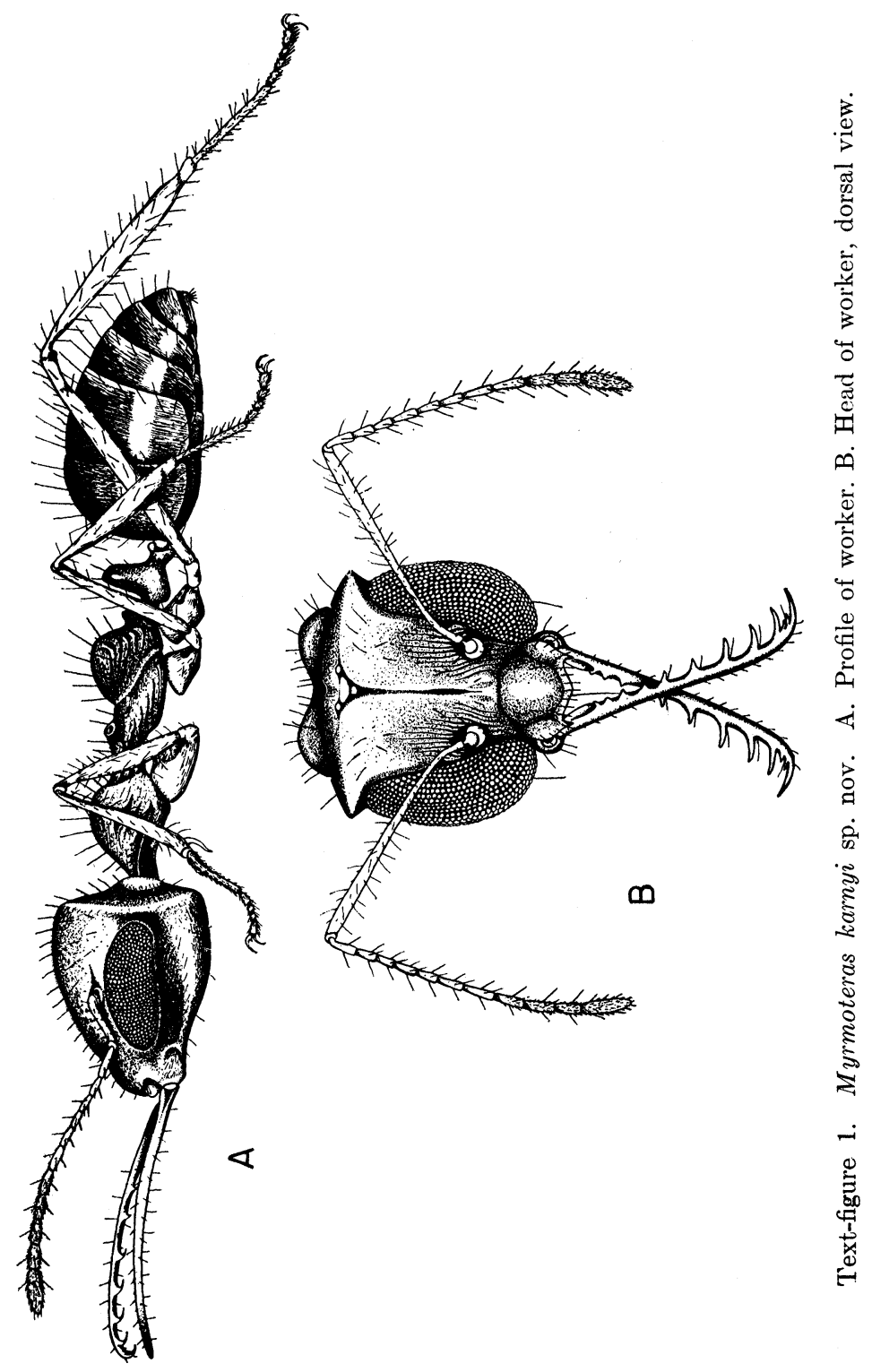


saddleshaped; mesonotal tubercles pronounced and their spiracular openings conspicuous. Petiole more or less pedunculate anteriorly and posteriorly, and provided with a thick, vertical scale. Tarsi long; tibiae more or less inflated.

Gaster with five visible segments; sting absent; pore of formic acid gland surrounded by a circlet of small hairs.

Female: resembles the worker; winged.

Anterior wing with the radial cell about equal to the cubital cell; a small discoidal cell.

Male: smaller than the female.

Head large, rounded posteriorly, and without transverse cephalic groove and occiptal bulge. Mandibles very short and rudimentary; without teeth. Antennae with 13 articles. Eyes, clypeus and antennal insertions as in the worker. Thorax, petiole, gaster and wings as in the female. Genitalia almost the same as in Prenolepis. Proventriculus provided anteriorly with a concave calyx, of which the sepals are thick, heavily chitinized, and reflected outwardly. Genotype: Myrmoteras binghami Forel, 1893. Burma ( $\Varangle)$.

Two new species were described and much additional information about these ants was provided by Creighton, when in 1930 he wrote at considerable length concerning the feeding relationships and other aspects of their behavior. He gave attention to the possibility of the phenomenon of retrosalience (backward leaping) occurring in Myrmoteras. Such behavior has been observed in Odontomachus, Anochetus among the ponerines, and in Strumigenys among the myrmicines. These genera, and also certain others in the tribe Dacetini, such as Acanthognathus, Orectognathus, Microdaceton and Epitritus, according to Creighton, may be described as "trapjawed". That is to say, they have elongated, narrow mandibles, articulated near the center of the anterior border of the head, and armed with various types of dentition. The mandibles when widely opened (extending in a plane at right angles to the long axis of the head), are operated by long trigger hairs attached either on the labrum or basal borders of the mandibles. These hairs when stimulated by appropriate 
prey cause the mandibles to snap shut, impaling small insects or other arthropods within their grasp. The closure is affected by powerful mandibular muscles, and the enlargement of these muscles has caused a protrusion and elongation of the occipital region of the head for their accommodation. The retrosalient behavior is attributed by Creighton to the effect of the mandibles snapping shut upon some object too hard and too large to be included in their bite. It is an ecological by-product, and he believes has no true functional significance in the lives of these ants.

Field observations on Myrmoteras are extremely scant, and so far no one has seen the feeding activities or retrosalience in any of the species. It can only be inferred from the structure of the Myrmoteras head and jaws, and the presence of long trigger hairs, that the behavior is similar to that known to occur in the various other trap-jawed genera mentioned above.

Wilson (1953) has recently added considerable interesting information about the feeding habits of North American dacetine ants, and has confirmed the previously described hunting behavior of these ants in which the prey (Collembola and a few other arthropods) are caught by the convulsive snap of widely opened mandibles.

Thus we appear to have some remarkable cases of convergence associated with trophic adaptations among ants. Two genera in the Ponerinae, a number of myrmicine genera, and one in the Formicinae have evolved independently food-seizing mechanisms of astonishing similarity, and these analogies are adequately described and illustrated in Creighton's account. A fertile field of ecological and behavioristic studies is available for any myrmecologist with the opportunity to observe Myrmoteras in its natural habitat.

The following is a description of a new species belonging to this genus.

\section{Myrmoteras karnyi sp. nov.}

Worker: Length $3.6 \mathrm{~mm}$; head index 0.92

Of the seven species heretofore recognized in the genus, Myrmoteras karnyi is most closely related to $M$. binghami by virtue of possessing a frontal furrow and by the pres- 
ence of cephalic striations or rugulae. Also, two minute denticles between the apical and the penultimate teeth constitute a further similarity. The lack of a furrow in barbouri and mjoebergi, as well as the nature of the head sculpture and the mandibular characters in these species, at once separate them from the new species. The forms with a frontal furrow, namely, binghami, donisthorpei, williamsi and bakeri, may all be distinguished from karnyi in various ways. In bakeri the dorsum of the head is entirely smooth, while in williamsi it is entirely coriaceous or covered with a sculpture of minute and contiguous punctures, giving the surface a matte appearance. The frons and clypeus of donisthorpei and binghami, according to Creighton, are reticulo-striate, but in the latter species the striae are feebler and rather fragmented. The head of karnyi possesses striations also, but these are less wavy, being curved only where they pass around the antennal insertions, and furthermore, they are confined to the frons. In addition, karnyi differs from binghami in that the mandibles each bear ten teeth (rather than nine), apart from the minute denticles between the two terminal teeth. The two basal teeth are themselves mere denticles, but nevertheless distinct, and all teeth show a gradual increase in size outward toward the apex of the mandible. The clypeus presents lateral furrows or depressions separating an elevated median portion from the marginal flanges, and such a condition seems to be lacking from binghami. The thorax of karnyi also contrasts noticeably with that of binghami, for the pronotum in profile is higher and more convex, and the mesonotum is decidedly saddle-shaped and narrowed, recalling the condition in williamsi, with strong longitudinal rugae traversing it. The mesonotal spiracles are sizable openings and are raised on prominent tubercles. The epinotum is as high as the pronotum, very convex resembling in general appearance the same structure in Myrmecocystus, and the angle between the basal and declivious faces is only weakly indicated. The petiole has short anterior and posterior peduncles, with a high, vertical scale, the front and rear surfaces of which slope slightly. The petiolar crest is flat but is inclined a little posteriorly and ventrally. 
Holotype: a single worker in the collection of the Zoologisch Museum en Laboratorium, Bogor (formerly Buitenzorg), Indonesia.

Type locality: Island of Sipora, in the Mentawai Archepelago off the west coast of Sumatra. The specimen was collected by H. H. Karny, \#22g, on October 31, 1924.

The following key has been modified from Creighton (1930) and Wheeler (1933), and includes the diagnostic features for the eight known species of the genus.

Key to the species of Myrmoteras

1. Frontal furrow well developed, extending back to the median ocellus .....................2

Frontal furrow absent or represented only by an obsolete impression which does not extend beyond the anterior third of the head

2. Head opaque, completely coriaceous, except the occipital fold. Length $3.9 \mathrm{~mm}$. . . . . . . . . . . . williamsi

Head smooth and shining; sculpture if present consisting of striae on the frons and clypeus ........3

3. Head entirely smooth. Female: length $4 \mathrm{~mm}$.... bakeri Frons, or frons and clypeus striate ...........

4. Mandibles 14-toothed; denticles between apical and penultimate teeth not well developed. Female: length $4.5 \mathrm{~mm}$. donisthorpei

Mandibles 9 or 10-toothed; denticles between apical and penultimate teeth well developed ...........5

5. Mandibles 9-toothed; frons and clypeus striate. Length $5.3 \mathrm{~mm}$ binghami Mandibles 10-toothed; frons striate, clypeus smooth. Length $3.6 \mathrm{~mm}$. karnyi

6. Head completely smooth and very shining. Length 5$5.6 \mathrm{~mm} . \ldots \ldots \ldots \ldots \ldots \ldots \ldots$. . . . . . . . . . . . .

Head subopaque, finely and feebly coriaceous . . . . . . 7

7. Mandibles with a pair of denticles between the apical and penultimate teeth; meso- and epinotum opaque. Length $6 \mathrm{~mm} . \ldots \ldots \ldots \ldots \ldots$.................... Mandibles without denticles between the apical and penultimate teeth; meso- and epinotum shining.

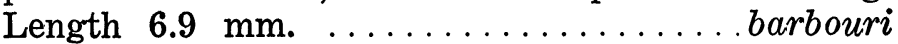


The genus Myrmoteras appears to belong to an archaic branch of the formicine subfamily, and according to Emery represents the relicts of an otherwise extinct group. The structure of the gizzard is obscure, though it is apparently primitive and not developed into the complicated mechanism found in the higher genera of the Formicinae. From Forel's figure (reproduced in the Genera Insectorum), it can be seen that the sepals of the proventriculus are only slightly reflected over the anterior end of the bulb, and appear to be similar to the condition observable in other primitive formicine genera (such as Anoplolepis, Plagiolepis, Melophorus and Myrmelachista) which are also near to the base of the stem from where these genera and other formicines have arisen. Nevertheless, Myrmoteras and an allied genus, Myrmecorhynchus, are considered by Emery sufficiently aberrant to be placed in a separate section of the subfamily, and his decision is based upon the nature of the gizzard. But he states that the organ in Myrmecorhynchus is more like those of the primitive genera mentioned above, and that the proventriculus of Myrmoteras is perhaps transitional to the condition seen in the more advanced genera.

The anatomy of the gastric valves in Myrmoteras are too poorly understood to allow an unequivocal phylogenetic placement of this genus, but whatever its eventual position, it is certain that these ants form a very unusual group. The most obvious facts in this connection are the elongate and sharply dentate mandibles, with trigger hair mechanisms, the modification of the cephalic structure to accommodate the mandibular muscles, and the enormous eyes fitted with very numerous facets. These structural characters are clearly associated with feeding habits, as can be ascertained from similar and convergently evolved morphological traits in other ant genera. These interpretations, together with a probably parallel but subsidiary accompaniment of the phenomenon of retrosalience, as deduced by Creighton, show that Myrmoteras, though undoubtedly archaic, has produced some very specialized structures and behavior associated with its nutritional requirements and feeding methods. The mixture of primitive and highly advanced adaptive features is not peculiar to these ants, but 
has turned up independently in diverse and unrelated taxonomic groups. It may be regarded as an indication of the resilience of the hereditary composition of living material, enabling the organism, through selection, to make necessary adjustments to, and exploitation of, the available habitats, irrespective of evolutionary primitiveness or specialization which the animal may show in regard to its closest relatives.

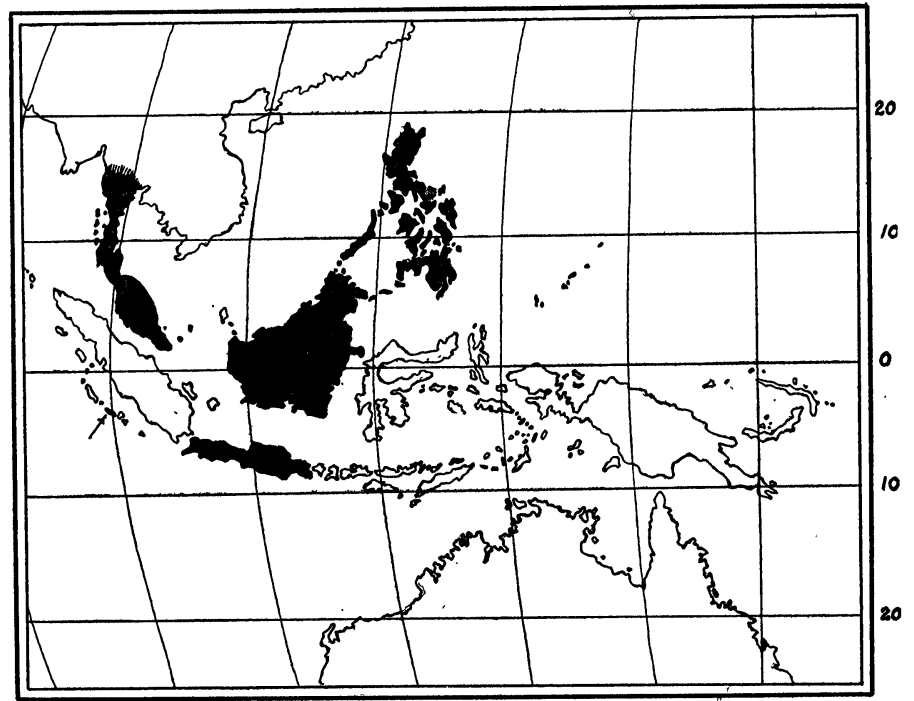

Text-figure 2. Estimated distribution of the genus Myrmoteras. Malay Peninsula, Philippines, Borneo, Java, and the Island of Sipora.

Apart from the extraordinary adaptations displayed by Myrmoteras, we are also concerned with geographic distribution of this group. The distribution suggests that of an ancient and perhaps once more widespread and flourishing genus. The modern representatives are few in number (8 species), and appear to be very rare as individuals even in their geographic headquarters, if we may judge from the paucity of material that has found its way into collections. The group was present, presumably, during the Tertiary Period, but there is no fossil evidence to confirm this assumption. In his study of the ants preserved in 
the Baltic Amber, Wheeler (1914) found that a number of Indomalayan genera and others which are tropicopolitan at the present time, had a much broader range, including northern Europe, during the Oligocene. However, Myrmoteras was not among them. Such negative information cannot show that these ants had not yet evolved, and on the other hand the primitive nature of the genus is a strong argument in favor of its origin at least by the Eocene or perhaps in Cretaceous times. Its absence from the Baltic Amber is a matter of conjecture, for advanced formicine genera like Prenolepis, Lasius, Formica, and Camponotus are abundantly represented and should have evolved no earlier than Myrmoteras. In this connection it should be noted that Plagiolepis is represented by a number of amber species. Peculiarities of behavior could hardly have kept Myrmoteras out of the resin traps for a great many ants of diverse habits are known from the amber. It seems reasonable to conclude that either the species of Myrmoteras were so rare (as they are today) that their chances of being preserved in fossil resin were drastically reduced, or that the range of the genus did not include the localities where amber was being formed. The latter possibility appeals to the writer to be much more probable.

The present distribution of these insects is outlined briefly in the list below. The reader is referred also to the adjoining map.

Myrmoteras bakeri Wheeler. Sandakan, Borneo - Type locality

Myrmoteras binghami Forel. Thaungyin Valley, Tenasserim, Burma - Type locality

Myrmoteras barbouri Creighton. Singdanglalia, JavaType locality

Myrmoteras donisthorpei Wheeler. Mt. Matang, Sarawak, Borneo - Type locality

Myrmoteras mjoebergi Wheeler. Mt. Tibang, Dutch Borneo - Type locality

Myrmoteras kemneri Wheeler. Tjibodas, Java - Type locality

Myrmoteras karnyi Gregg. Sipora, Mentawai IslandsType locality 
Myrmoteras williamsi Wheeler. Los Baños, Philippine Islands-Type locality; Dumaguete, Philippine Islands

Dr. Brown informs me (in litt.) of an additional record of Myrmoteras taken from the island of Hainan (Ta Han, and collected by J. L. Gressitt), which thus considerably extends the known range of the genus. The specimen is a male, and has not been identified definitely with any of the known species. It may belong to donisthorpei, but until it can be associated with other castes, its determination is uncertain.

The scarcity of these ants is readily apparent from the above list in that all but one are known only from the type localities, and very little material beyond the type specimens seems to be known. M. bakeri is represented by the female and male, donisthorpei by the female caste, binghami, barbouri, mjoebergi, kemneri, and karnyi by the worker caste, and williamsi by worker, female, and male castes.

Some of the differences among these species may seem rather slight, and might be interpreted as indicating subspecific status. Wheeler thought this might be the case between barbouri and his new form kemneri, but in an ancient stock it appears more likely that the surviving species are relicts of a formerly broadly dispersed fauna, and a group in which the process of speciation had completely sorted out and separated an array of forms rather than one which presented the early (subspecific) stages of differentiation. For this reason, the writer is inclined to the belief that the eight species or forms so far discovered will be confirmed as specifically distinct when more extensive information is available.

It will be noticed that the distribution map implies complete occupancy by Myrmoteras of Borneo, Java, the Philippines and the Malay Peninsula. This was done despite our fragmentary knowledge and the very limited actual localities where the ants have been taken, because the genus if present on an island at all, probably exists at numerous stations. In addition, such relatively primitive ants may be holding on in the face of a more advanced fauna of higher formicines, in which case they would be expected to occur in the undisturbed forest areas rather than locations 
subject to human interference, and when these forests are more thoroughly collected it seems certain many more specimens of Myrmoteras will come to light. The new species, karnyi, is from an island near the coast of Sumatra, consequently it is logical to suppose that the genus is represented by this species or some other form native to this large island of the East Indies, especially since adjacent major islands, and Malay, possess the ants. However, in the absence of any records known to me from Sumatra, it is thought best to leave the island unshaded.

Acknowledgement is due Dr. William L. Brown for the opportunity to describe and figure the specimen upon which the latest species of Myrmoteras is based. Dr. Creighton has also examined the specimen and I have had the benefit of his opinion in proposing the new form.

\section{Literature}

Chapman, J. W. and S. R. Capco.

1951. Check list of the ants of Asia. Monog. Inst. Sci. Tech., Manila, Monog. 1, $327 \mathrm{pp.}$

Creighton, W. S.

1930. A review of the genus Myrmoteras. Jour. N. Y. Ent. Soc., $38: 177-192,2$ figs., 1 pl.

Emery, C.

1925. Genera Insectorum. Fase. 183, Subfam. Formicinae.

Forel, A.

1893. Note préventive sur un nouveau genre et une nouvelle espèce de Formicide. Ann. Soc. Ent. Belg., 37:607-608.

WHEELER, W. M.

1914. The ants of the Baltic Amber. Schrift. d. Physik-ökonom. Gesell. Königsberg, 55:1-142.

1919. The ants of Borneo. Bull. Mus. Comp. Zool., 63:43-147.

1933. A new Myrmoteras from Java. Proc. New England Zool. C!ub, $13: 73-75$.

WILson, E. O.

1953. The ecology of some North American dacetine ants. Ann. Ent. Soc. Amer.. $46: 479-495$. 

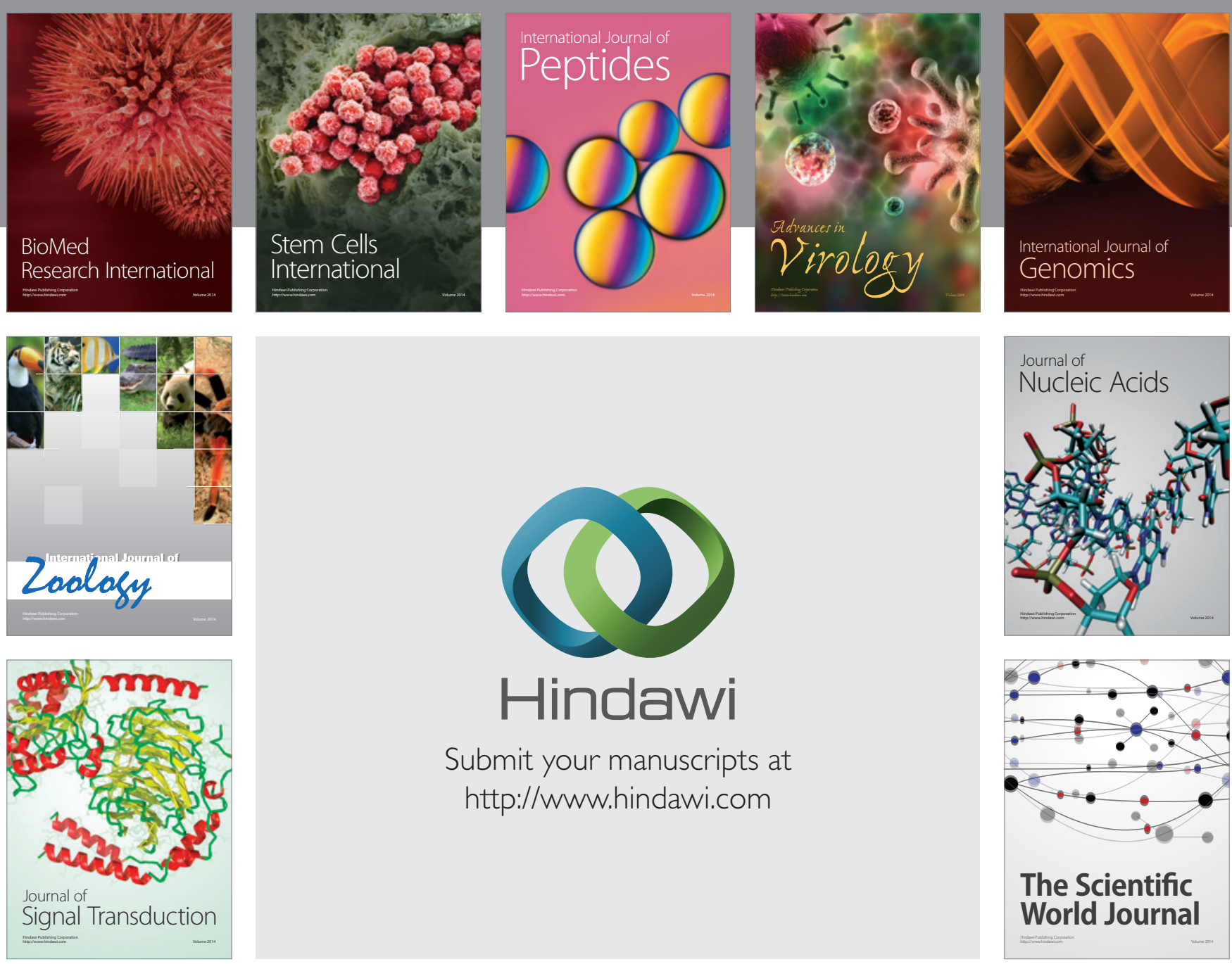

Submit your manuscripts at

http://www.hindawi.com
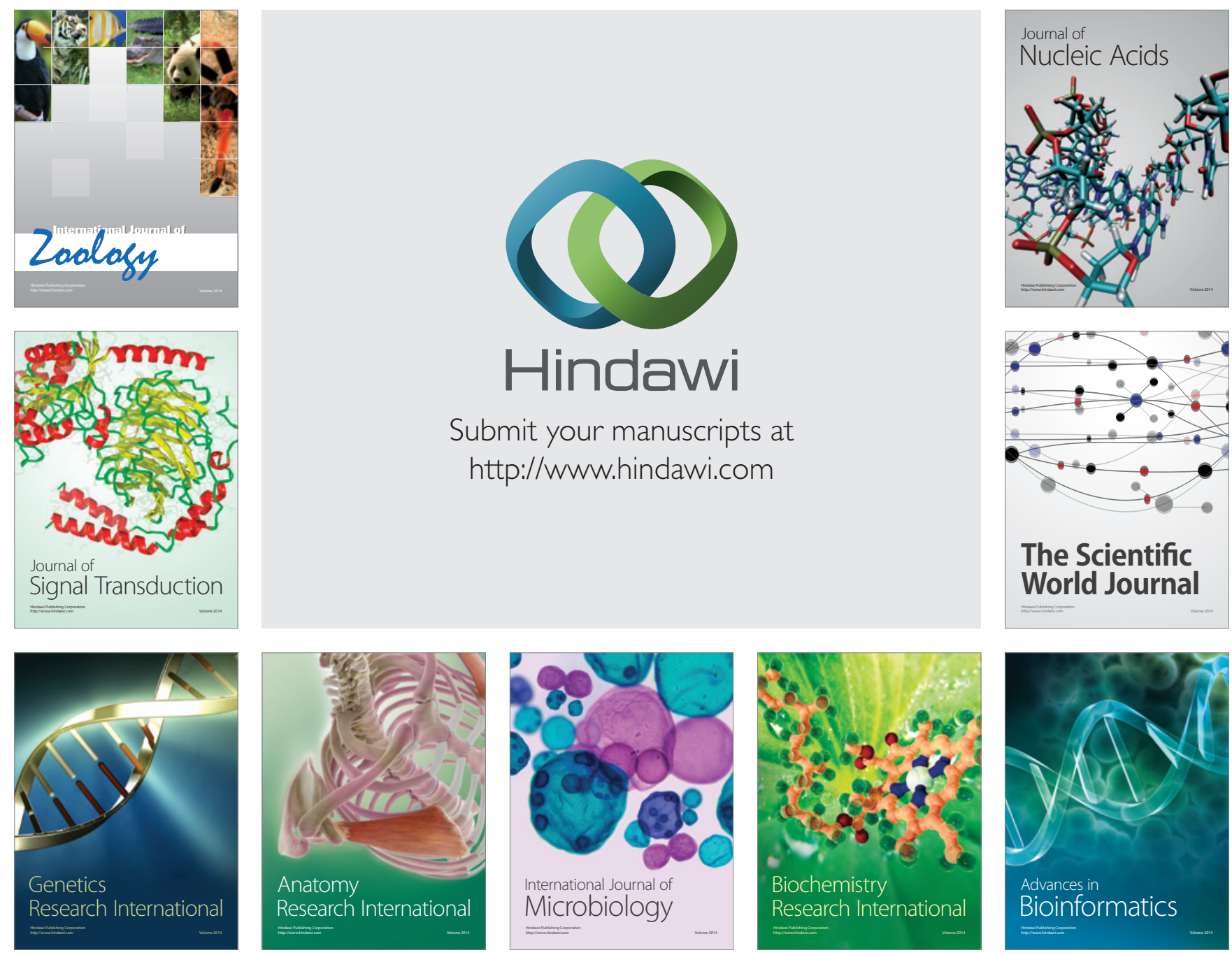

The Scientific World Journal
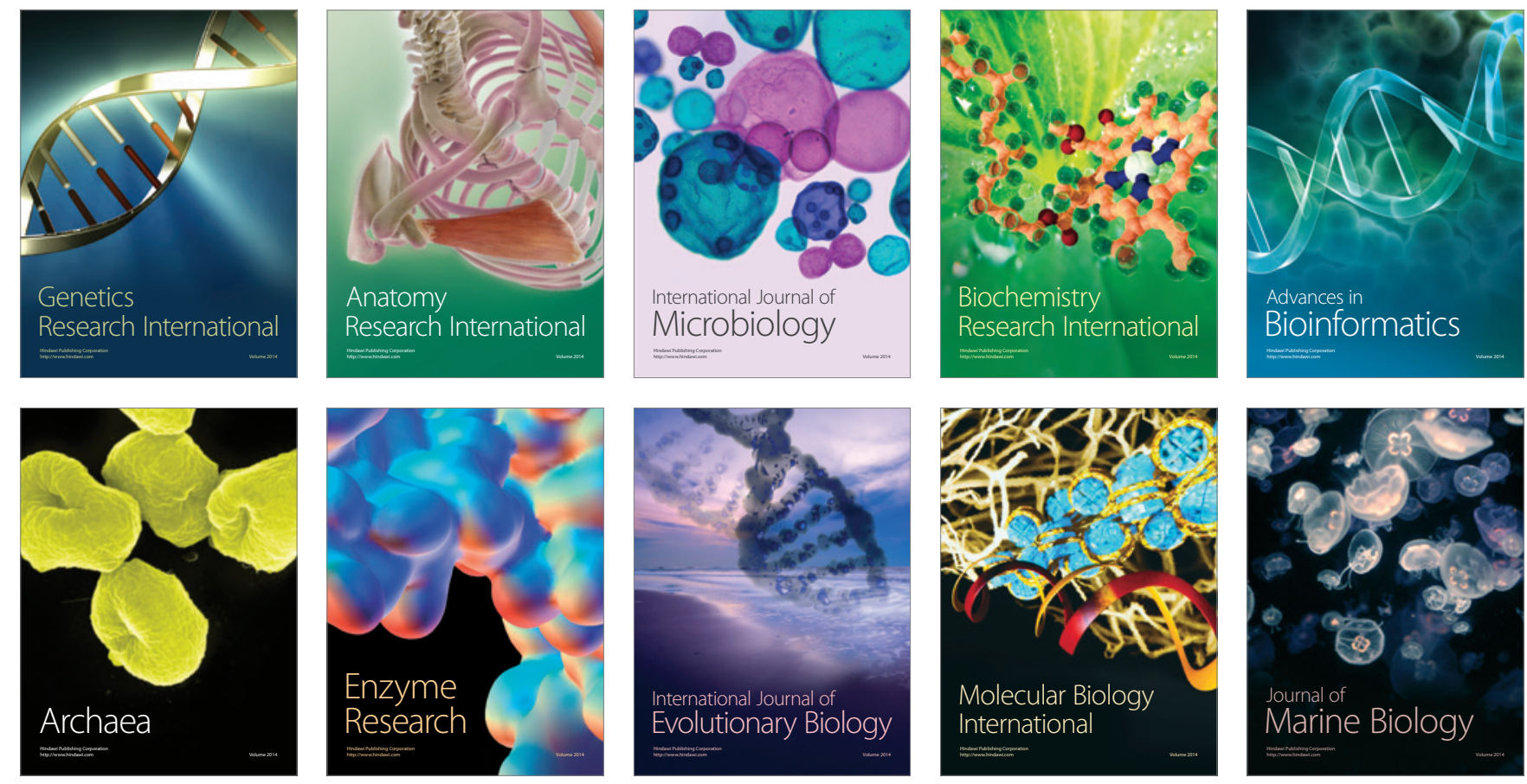